Winter 2004

\title{
Federalism, Through a Global Lens: A Call for Deferential Judicial Review
}

Alfred C. Aman

Indiana University Maurer School of Law, aaman@indiana.edu

Follow this and additional works at: https://www.repository.law.indiana.edu/ijgls

Part of the International Law Commons, and the Judges Commons

\section{Recommended Citation}

Aman, Alfred C. (2004) "Federalism, Through a Global Lens: A Call for Deferential Judicial Review," Indiana Journal of Global Legal Studies: Vol. 11 : Iss. 1 , Article 5.

Available at: https://www.repository.law.indiana.edu/ijgls/vol11/iss1/5

This Symposium is brought to you for free and open access by the Law School Journals at Digital Repository @ Maurer Law. It has been accepted for inclusion in Indiana Journal of Global Legal Studies by an authorized editor of Digital Repository @ Maurer Law. For more information, please contact rvaughan@indiana.edu.

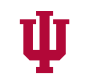

JEROME HALL LAW LIBRARY

INDIANA UNIVERSITY

Maurer School of Law
Blooming ton 


\title{
Federalism Through a Global Lens: A Call for Deferential Judicial Review
}

\author{
Alfred C. Aman, Jr."
}

\section{INTRODUCTION}

This article examines the effects of judicial review in federalism cases on governmental flexibility and creativity at the national level. It argues that the global era in which we now live and the New Deal of the 1930s and beyond have at least one thing in common, and that is a need for creative approaches at the federal level to perceived societal problems. New regulatory approaches often take the form of new mixtures of federal and state power, as well as new public and private partnerships. While it may seem ironic, some of the deferential constitutional interpretive approaches forged by the Supreme Court during the New Deal may be best suited for the political experimentation now necessary, if various levels of government and nonstate actors are to adapt successfully to the realities and demands of a global economy.

During the New Deal, we were coming to grips as a nation with the realities and societal needs of a national economy. Communications had become national, as had our transportation needs and capabilities. Commerce was now national, as were the markets for securities, labor, energy, and natural resources. ${ }^{1}$ The Supreme Court initially struck down federal legislation seeking to regulate aspects of these national markets, as if any changes that were to occur had to conform to a vision of the economy formulated in terms of nineteenth century ideologies and technologies. ${ }^{2}$ Eventually, with what we have come to refer to as the

*Roscoe C. O’Byrne Professor of Law, Indiana University School of Law and Director, Institute for Advanced Study, Indiana University.

1. See generally E.W. Hawley, The New Deal and the Problem of Monopoly (1966) (discussing the problem of aligning the theories of democracy and industrialization and of nationalizing the American economy during the New Deal).

2. See, e.g., Louisville Joint Stock Land Bank v. Radford, 295 U.S. 555 (1935) (Frazier-Lemke act); A.L.A. Schechter Poultry Corp. v. United States, 295 U.S. 495 (1935) (section 3 of National Industrial Recovery Act); R.R. Ret. Bd. v. Alton R.R., 295 U.S. 330 (1935) (Railroad Retirement Act); Pan. Ref. Co. v. Ryan, 293 U.S. 388 (1935) (section 9 of National Industrial Recovery Act). But see Perry v. United States, 294 U.S. 330 (1935); Nortz v. United States, 294 U.S. 317 (1935); Norman v. Baltimore \& Ohio R.R., 294 U.S. 240 (1935), all sustaining the validity of Joint Resolution of June 5, 1933, H.R.J. Res. 192, 73d Cong. (1933) (declaring gold payment contracts illegal). 
"switch in time that saved nine," an overreaching Supreme Court learned to respect the political experimentation that a majority of Congress believed was necessary. ${ }^{3}$ When it came to judicial review of the economic legislation of the New Deal, the Court developed an appropriately deferential rational basis test that it applied to these statutes. New Deal legislation easily survived such review. ${ }^{4}$ As a result of the application of this new deferential standard of judicial review, the Court essentially stayed out of the economic politics of the New Deal. ${ }^{5}$

Today, we are still learning how best to live with and, if possible, govern a global economy. A variety of questions confront us. How do we govern globalization? And what exactly is globalization? Is it a set of neoliberal socioeconomic processes that know few limits or boundaries and, like the markets that drive them, simply extend, in an inevitably linear fashion, over, through, and beyond the governmental structures of nation states? Or are these global processes capable of transformation or resistance at the national and local levels? Can citizens at the domestic level of governance not only resist these forces but transform them as well, by taking into account noneconomic values and concerns, such as those traditionally associated with the New Deal's social safety net-welfare, social security, health care, etc? How are the voices of citizens who favor such views to be heard, especially if these issues are increasingly left to the private sector?

Globalization can mean many things-from pure laissez-faire markets to the regulatory demands of the World Trade Organization (WTO). The kind of global perspective that lawmakers adopt will affect how they choose to resist or facilitate the changes that globalization appears to promote. It also will affect the way they use distinctions that once hel ped us to allocate power and sort out the responsibility for its exercise. Given the de-centered nature of the global state, ${ }^{6}$ however, and the ways in which the global economy now integrates itself throughout national economies, distinctions developed in the context of a national economy, distinctions such as public and private, state and federal, national and international, domestic and foreign, or local and global, no longer accurately capture or reflect the new power relationships to which these distinctions once applied. There is a tendency on the part of courts to treat changes in the allocation of what is public

3. See, e.g., West Coast Hotel Co. v. Parrish, 300 U.S. 379 (1937).

4. Id. See also Phillips Petroleum Corp v. Wisconsin, 347 U.S. 672 (1954).

5. See Alfred C. Aman, Jr., Administrative Law in a Global Era 8-24 (1992).

6. See Alfred C. Aman, Jr., The Globalizing State: A Future-Oriented Perspective on the Public Private Distinction, Federalism, and Democracy, 31 VAND. J. Transnat'L L. 769, 812-16 (1998) [hereinafter The Globalizing State]. 
or what is private, or what is federal and what is state, as if they all involved zerosum shifts of power; however, globalization does more that reallocate power among pre-existing categories. It changes the power relationships within those categories, requiring a reinvention, if you will, of the very meaning of those terms.

The role that courts are playing and will play in the future in this process of reinvention is crucial and can have long-run significance; however, this role is usually indirect. The reforms that produce the litigation coming before the courts are not labeled "The Global Deal." Rather, the cases tend to involve the increasing use of hybrid public/private arrangements where private enterprise now provides services once handled exclusively by the state. Citizens are now, for example, increasingly described as consumers or clients in such privatized arrangements. Courts are asked to determine, for example, the liability of private prison guards who negligently handcuffed a prisoner assigned to a private facility. ${ }^{7}$ Are privatized prisons private in the sense we might use the word when referring, perhaps, to IBM, or is this a new way for the public to carry out its collective responsibilities? What once was public is now private. Or courts may find themselves involved in cases involving federal statutes that regulate what we expect states to do-for example, tend to local crime issues such as the possession of guns on school grounds or end domestic violence directed against women. ${ }^{8}$ What once was traditionally a state concern is now addressed at the federal level. Questions involving safety and various forms of violence increasingly are viewed as national in scope. What is really going on here and what are domestic courts to do? To paraphrase Justice Oliver Wendell Holmes, it is my hope that domestic courts will see the global in the particular, and rule accordingly. But short of that, at least in the constitutional realm, it is crucial for courts to recognize that this is a time for experimentation and politics at all levels of government, not the imposition of nineteenth century concepts of sovereignty that so often form the basis of Supreme Court decisions involving federalism concerns.

Globalization, as I use the term, refers primarily to processes that have denationalizing effects on the states. Devolution, quite literally, fragments social issues by denationalizing solutions and, inevitably, the nature of the problems involved as well. Devolving welfare responsibility or housing for the poor to the state level (2000). 
means individual states can and will vary not only in their approaches to such issues, but in the priority they give to them. As states compete for investment and the retention of taxpayers, they have distinct incentives to minimize the costs of redistributive programs such as welfare, Medicaid, or poverty programs in general. Yet, these were precisely the kinds of programs that Congress tried to (and to a large extent did) send back to the states in the 1990s. The agenda was, if not the elimination of such federally supported programs, their minimization in terms of importance and costs at the federal and national level. Though the theory of devolution is that it increases democracy by bringing decisions closer to those directly affected by them, it is, in certain contexts, actually more likely to narrow the range and effectiveness of democratic participants by minimizing the political strength of groups whose members are more effective and whose numbers are more impressive on a national level than on a local level. ${ }^{9}$

The turn toward devolution in Congress and the revival of doctrines of federalism in the courts can have untoward effects on politics and policy makers at all levels of government, particularly when the changes involved are premised on a conception of the state that predates the global economy as we know it today. The politics giving rise to such reforms in Congress can, of course, change; however, constitutional decisions by the courts are more lasting. They also, inevitably, have a way of framing the political debates that should go on in the legislative and executive branches of government. This article looks at federalism through a global lens, and argues that the analytic tools the Supreme Court has used in recent federalism opinions are inappropriate for the nature of government and governance today. The article concludes with a plea for judicial restraint and a doctrinal approach to such power allocation issues not unlike that used by the courts during the New Deal. The similarity in deferential approaches to judicial review should not, however, be associated with retaining or returning to an earlier time, as far as the substance and methods of regulation are concerned. Rather, deference is to ensure that there can be a maximum of innovation and creativity between and among various levels of government and nonstate actors as well, when it comes to coping with societal problems that are global in scope today.

9. See, e.g., Matthew A. Crenson \& Benjamin Ginsberg, Downsizing Democracy: How America Sidelined its Citizens and Privatized its Public 232-33 (2002). 


\section{Globalization and Federalism}

Since the founding of the republic, power in the United States has flowed from the states to the national government. ${ }^{10}$ As local economies became more integrated with a growing national economy, the logic of Supreme Court decisions, particularly those after 1937, almost always resolved disputes between federal and state levels of government in favor of national power. ${ }^{11}$ Post-New Deal, the outcomes in cases involving the scope of the Commerce Clause of the Constitution seemingly had become such a foregone conclusion that it prompted then Justice Rehnquist's pointed concurrence in judgment in Hodel v. Virginia Surface Mining and Reclamation Association:" "Although it is clear that the people, through the States, delegated authority to Congress to 'regulate Commerce ... among the several States,' ... one could easily get the sense from this Court's opinions that the federal system exists only at the sufferance of Congress." ${ }^{33}$ Indeed he viewed the proposition that Congress, in our system of government exercises only power delegated to it as "one of the greatest 'fictions' of our federal system."14

Chief Justice Rehnquist now speaks for a majority on a Court that approaches federalism issues in a way far more open to state autonomy and is quite willing to reject expansive readings of the Commerce Clause. The legacy of the Rehnquist court may very well be that in the end its constitutional approach to federalism ultimately prevailed. The Court has taken issue with attempts by the federal government to "commandeer" state bureaucracies to carry out federal mandates. ${ }^{15}$ It has breathed new meaning into the Tenth Amendment, arguing,

10. See Philip B. Kurland, The Role of the Supreme Court in American History: A Lawyer's Interpretation, 14 Bucknell Rev. 16, 16-26 (1966). Parts II and III of this article draw heavily on a revised and updated version of this article that first appeared as The Globalizing State, supra note 6, at 848-68. A modified version of these sections will also appear in Alfred C. Aman, Jr., The Diminishing Deficit: Taming Globalization through Law Reform (forthcoming).

11. See West Coast Hotel Co. v. Parrish, 300 U.S. 379 (1937) (upholding the constitutionality of the Washington Minimum Wages for Women Act, in the so-called "switch-in-time that saved nine" case); see also Felix Frankfurter, Mr. Justice Roberts, 104 U. PA. L. Rev. 311, 314-15 (1955) (showing vote in West Coast Hotel was taken before legislation to expand court was proposed).

12. Hodel v. Va. Surface Mining \& Reclamation Assoc., Inc., 452 U.S. 264 (1981).

13. Id. at 307-08, (quoting U.S. Const. art. I, §8, cl. 3) (citations omitted).

14. Id. at 307 .

15. See, e.g., New York v. United States, 505 U.S. 144 (1992); Gregory v. Ashcroft, 501 U.S. 452 (1991). 
for example, that regulation of guns near schools is too local an issue to be supported by the Commerce Clause of the Constitution. ${ }^{16}$ The reasoning in these cases suggests a shift in the Court's methodology and philosophy regarding federal-state issues. This shift in emphasis from federal power to autonomous state power coincides with economic and political shifts in the global economy that also encourage the decentralization of power. Further, the Court's approach to federal-state relations diminishes the flexibility of federal and state policymakers to experiment with new regulatory approaches, running the risk of substantially undermining the range of policy alternatives and administrative structures necessary for the global state to be effective. ${ }^{17}$

Consider, for instance, the Court's invalidation of the Violence Against Women Act (VAWA) in United States v. Morrison. ${ }^{18}$ Over the dissent of Justice Souter, joined by three other Justices, the Court held that Congress does not have the power to pass VAWA. In support of his argument that VAWA is a constitutional exercise of Congress' power, Souter cites "the state support for the Act based upon the States' acknowledged failure to deal adequately with genderbased violence in state courts, and the belief of their own law enforcement agencies that national action is essential." 19 Justice Breyer, in a separate dissent in which three Justices joined, emphasizes the procedures Congress engaged in for the purpose of protecting federalism values:

It provided adequate notice to the States of its intent to legislate in an "are[a] of traditional state regulation." And in response, attorneys general in the overwhelming majority States (38) supported congressional legislation, telling Congress that "[o]ur experience as Attorneys General strengthens our belief that the problem of violence against women is a national one, requiring federal attention, federal leadership, and federal funds." 20

16. United States v. Lopez, 514 U.S. 549 (1995).

17. For a discussion of federalism advocating an alternate view, i.e., that federalism is an empowerment of the national government, see Erwin Chemerinsky, The Value of Federalism, 47 F LA. L. Rev. 499, 504 (1995) ("[I]t is desirable to have multiple levels of government all with the capability of dealing with the countless social problems that face the United States as it enters the 21 st century.")

18. United States v. Morrison, 529 U.S. 528, 598 (2000).

19. Id. at 653 (Souter, J., dissenting).

20. Id. at 661 (Breyer, J., dissenting) (alteration in original) (citations omitted). 
The states' support for VAWA was further illustrated by the fact that when the Act was challenged in court, "[t]hirty-six of them ... filed an amicus brief in support of [the United States], and only one State [took] the respondents' side." Breyer concluded from the procedures adopted by Congress and the overwhelming support of the states that "the law before us seems to represent an instance, not of state/federal conflict, but of state/federal efforts to cooperate in order to help solve a mutually acknowledged national problem."22

The Court's constitutionalized shift in the power relationships between the nation and the states, its underlying rationale for this change, and a trend toward devolution in Congress itself are all likely to encourage more competitive models of the state, at the expense of developing more cooperative understandings of issues at both the national and the international levels of government. The emphasis on the individuality of states increases the transaction costs of reaching agreements that could apply to all states. In a sense, an extreme view of federalism would make national legislation as difficult as negotiating multilateral treaties. This is not to argue that a race to the bottom is inevitable in such a situation, ${ }^{23}$ but it does mean that creative, cooperative approaches to issues may be constitutionally excluded when they should be subject to political debate. Indeed, the pre-New Deal era was one characterized by many issues now prevalent at the global level, from child labor to monopolistic private power. The principles of federalism, carried too far, can exacerbate the most significant externalities of globalization: democracy deficits and poverty.

\section{A. A Global Perspective on Federalism}

The strong-state assumptions currently used by the Supreme Court in its analysis of federalism issues, coupled with its emphasis on dual citizenship, cost, and accountability no longer sufficiently capture the heterogeneous quality of states as actors in today's global economy. Nor do the assumptions capture the multi-centric complexities of the relationships that now typify the transnational actors that states seek both to attract and to control or, at least, influence. The

21. Id. at 654 (Souter, J., dissenting).

22. Id. at 662 (Breyer, J., dissenting).

23. See, e.g., Richard L. Revesz, Rehabilitating Interstate Competition: Rethinking the "Race-tothe-Bottom" Rationale for Federal Environmental Regulation, 67 N.Y.U. L. Rev. 1210 (1992). But see, Daniel C. Esty, Revitalizing Environmental Federalism, 95 Mıcн. L. Rev. 570, 627-38(1996). 
Court's emphasis on democracy and accountability at the state level overestimates the degree of choice states have when working by themselves, especially when the problems involved simultaneously include state, federal, and international components. It also underestimates the cosmopolitan nature of citizens today, and the fact that individuals are able to differentiate among various levels of power with which they are involved and with which they identify. A citizen of a particular state is also a citizen of the U.S. and a global citizen as well. Individuals carry all of these identities with them on a daily basis. ${ }^{24} \mathrm{Our}$ political processes need to reflect such complexity, not compress it. The power relationships now involved due to globalization are multi-dimensional, not simply federal or state, national or international, public or private.

Paradoxically perhaps, globalization exerts a downward pull when it comes to the exercise of both federal and state power, providing incentives for more state autonomy and power and more local authority within states..$^{25}$ At the same time, globalization also creates pressures from outside the nation-state to take actions that allow international solutions to problems such as ozone depletion or global warming. ${ }^{26}$ In addition, there are horizontal competitive forces at work as well, brought about by transnational corporations, with economic power sometimes approximating the power of a small state and with the capability of locating their operations anywhere in the world. Indeed, a multi-centric world, consisting of non-sovereign power centers pursuing their own private interests, adds another important power dimension to federalism issues. As a consequence, issues involving sovereignty and democracy arise that go beyond the traditional discourse of federalism, as it has developed so far. This is true of citizenship issues as well, as citizens in a global context regularly function on multiple levels of political awareness.

24. See Martha C. Nussbaum, Patriotism and Cosmopolitanism in For Love of Country: Debating the Limits of Patriotism 2, 2-20 (Joshua Cohen, ed., 1996); see also Kwame Anthony Appiah, Cosmopolitan Patriots in For Love of Country: Debating the Limits of Patriotism, supra, at $21-$ 29.

25. See Alfred C. Aman, Jr., A Global Perspective on Current Regulatory Reform: Rejection, Relocation, or Reinvention?, 2 Ind. J. Global Legal Stud. 429, 435-37 (1995). For an argument that much of what courts claim are rationales for federalism are, in reality, arguments for decentralized management, see Edward L. Rubin \& Malcolm Feeley, Federalism: Some Notes on a National Neurosis, 41 UCLA L. Rev. 903, 914 (1994).

26. See Richard Elliot Benedick, Ozone Diplomacy - New Directions in Safeguarding the Planet (1991). 


\section{B. The Downward Pull of Globalization}

Globalization encourages increasingly intense international competition among nations, states, and cities to attract and keep industries that they believe can create economic growth in their jurisdictions. Though the location of a plant or manufacturing operation turns on numerous, primarily cost-related factors, low taxes and the imposition of minimal regulatory costs usually constitute important elements of a jurisdiction's strategy to attract industry and jobs to a particular locale. ${ }^{27}$ The tax and regulatory policies devised on the local level to attract industries to a certain locale are often the result of decision-making processes that are more akin to local corporatism than to more traditional forms of democracy. Indeed, one commentator has noted, based on a study of Japanese investment in the Midwest, that a kind of embedded corporatism best describes the process by which new investment is sought. ${ }^{28}$ This involves, among other things, "an activist local state working with the business class to attract foreign investment and thereby stimulate the local economy." 29 As a result of agreements among business, government, and labor, substantial tax relief and various other economic and cultural incentives are commonly offered as forms of currency in this global competition for business. ${ }^{30}$

Individual states and municipalities within the United States, eager to attract such new investment and to retain its current industries, have a great interest in gaining control of as many factors as possible that affect firms' decisions to locate to or remain in the jurisdiction. They can create currency for global competition when it comes to providing services (such as welfare) more efficiently than neighboring states, ${ }^{31}$ thereby lowering taxes or entering into incentive based arrangements with companies they wish to attract to their locale. ${ }^{32}$ But this need not always lead to fewer or less adequately funded services for the poor if those investments can pay off in the jurisdiction involved. For example, if a state

27. See Robert Perrucci, Japanese Auto Transplants in the Heartland: Corporatism and Community 41-76(1994).

28. Id. at $125-45$.

29. Id. at 17.

30. Id. at 131-34.

31. See Alfred C. Aman, Jr., Administrative Law for a New Century, in The Province of Administrative Law 101 (Michael Taggart ed., 1997).

32. J. William Hicks, The Listing of Daimler-Benz A.G. Securities on the NYSE: Conflicting Interests and Regulatory Policies, 37 German Y.B. of INT'L L. 360-85 (1994). 
depends on low wage labor to attract certain kinds of industry, it may not only have very favorable labor laws, but also low income housing to attract the labor force it needs. ${ }^{33}$ Of course, the key point is that economic competition drives social policy. A sense of decency or what is best for society in the long term are rationales that are not nearly as persuasive as the ability to be maximally competitive in the global economy.

Closely related to global incentives for regulatory cost-cutting and the imposition of lower taxes at the federal, state, and local levels is the increased desire of each particular jurisdiction seeking increases in economic investment to control its own costs. Relocating federal regulatory responsibility for costly programs in the individual states arguably gives states the opportunity to create more global currency by maximizing the efficiency with which they provide such services, allowing them to reallocate scarce funds in more globally effective and competitive ways.

There may, of course, be some forms of global competitive currency individual states should not be allowed to create. ${ }^{34}$ And there may be national interests that should take precedence over state concerns, particularly when social safety net issues are involved. Level playing fields, however, are not necessarily sought by states when their primary motivation is to compete more effectively with other states. Moreover, a level playing field within the United States would not solve the competitive problems of states arising from their competition with other countries and regions. The multi-centric aspects of the global economy stem from the multiple state and non-state power centers capable of affecting where investments may or may not occur. All of these pressures militate in favor of decentralized and denationalized decision making.

\section{The Pull from the Top-National and International Pressures}

The increase in states' power to control the costs imposed on their inhabitants and potential investors through devolution is, however, only one aspect of current federalism trends. There are also forces operating simultaneously to reinforce federal powers. National standards and approaches may be necessary to

33. Crenson \& Ginsberg, supra note 9, at 232.

34. For example, private prisons' costs should not be lower because the efficiencies of the private sector were achieved at the expense of constitutional protections available to prisoners. 
prevent the creation of illegitimate global currency, ${ }^{35}$ stemming, for example, from the denial of constitutional rights. They also are necessary to achieve certain levels of regulatory uniformity if businesses are to avoid an unnecessarily complex patchwork quilt of state rules and regulations. ${ }^{36}$ More important, there also are issues such as the environment, in which it is in the interest of nationstates to play an active regulatory role at the global level. Effective national participation at the global level requires a national "presence" in certain domestic areas affected by these global concerns. And indeed, international agreements and multilateral approaches have been increasing at a rapid rate. ${ }^{37}$ For example, if there were no effective national control over air pollution, it would be very difficult for the national government to speak for all fifty states and enter into serious negotiations at the global level.

The ability of the national government to participate effectively in global issues at the international level also can help mitigate the extremes of global competition. Along with the trend toward devolution of federal power to the states, there is also at least the beginning of an evolutionary trend involving the national government sharing more directly in the responsibilities of international governance. ${ }^{38}$ At the national level, this trend toward multinational decision making and problem solving often expresses itself negatively in debates over the undue restriction of national sovereignty, ${ }^{39}$ but international cooperation and multinational agreements are nonetheless increasing. ${ }^{40}$ Yet it would be a mistake to

35. See, e.g., Diane P. Wood, United States Antitrust Law in the Global Market, 1 IND. J. Global Legal Srud. 409 (1994); see generally Daniel C. Esty, Toward Optimal Environmental Governance, 74 N.Y.U. L. Rev. 1495 (1999) (arguing that regulation should maximize social welfare).

36. See Daniel C. Esty, Stepping up to the Global Environmental Challenge, 8 Fordham Envtl. L.J. 103, 108-11 (1996); see also, J. William Hicks, Protection of Individual Investors Under U.S. Securities Laws: The Impact of International Regulatory Competition, 1 Ind. J. Global Legal Stud. 431 (1994).

37. For example, according to the Multilaterals Project at Tufts University, at least 36 major multilateral environmental treaties have opened for signature since 1972. See Tufts University, Multilaterals Project, at http://fletcher.tufts.edu/multilaterals.html (last visited Dec. 9, 2003).

38. See, e.g., id.; World Commission on Environment and Development, Our Common Future (1992).

39. For example, see the academic debate over sovereignty that occurred when the World Trade Organization was established. See also Fast Track Legislation: Hearings Before the Senate Commission On Commerce, Sci, and Transp., 1997 WL 605646 (F.D.C.H) (Sept. 30, 1997) [hereinafter Hearings] (comments by Sen. Ernest F. Hollings, Member, Senate Comm. on Commerce, Science and Transportation).

40. For a public choice perspective on this overall increase in international agreements, see Enrico Columbatto \& Jonathan Macey, A Public Choice Model of International Economic Cooperation and the Decline of the Nation State, 18 CARdozo L. Rev. 925 (1997). 
assume that recourse to an international approach always means national legislation or national regulation. Indeed, as we shall see below, delegating authority upward to an international organization such as the WTO can also result in the imposition of a market-oriented, deregulated approach domestically, reinforcing decisions by either the Congress or the Court in favor of devolving power to the states. Such an approach to international delegation can also increase competition at both the global and domestic levels. Nevertheless, international cooperation and regulation highlight the importance of the national government's ability to play an active role at the domestic level even in the context (and even because) of such supranational governance. To the extent that federal power is limited in this regard, enforceable international regulatory regimes are more difficult to create than when only one major decision maker is involved. ${ }^{41}$

\section{Horizontal Forces and the Transnational Corporation}

Federalism is traditionally seen in vertical terms, ${ }^{42}$ involving a flow of power between state and federal centers of authority. Viewed in these terms, a global perspective introduces not only an additional vertical level of power (the international "level") but additional horizontal dimensions as well. A global perspective emphasizes the fact that states outside the United States now play an increasingly important role when it comes to global competition and it also highlights the significant role nonstate actors, such as multinational corporations, now play in influencing local legal regimes and policies. ${ }^{43}$ Their ability to render a sense of place relatively irrelevant when it comes to deciding where to locate a plant, for example, substantially threatens the ability of individual governments, state or federal, to regulate the activities of such entities effectively. The fact that capital moves relatively freely from state to state also means that investment can

41. See, e.g., Hearings, supra note 39.

42. Of course, it can be horizontal as well, for example, when states try to take advantage of other states. See, e.g., Kassel v. Consolidated Freightways Corp., 450 U.S. 662 (1981). These issues, however, involve only states and are controlled by the relationship of state law to the Commerce Clause.

43. For a discussion of the power of transnational corporations and their impact on politics, see Susan Strange, The Diffusion of Power in the World Economy 44-54 (1996) (“the progressive integration of the world economy has shifted the balance of power away from states toward world markets. That shift has led to the transfer of some powers in relation to civil society from territorial states to TNC's.") [hereinafter Diffusion of Power]. 
sometimes leave as quickly as it came. ${ }^{44}$ The jurisdictional difficulties faced by states trying to influence such actors cannot be dealt with as they were during the New Deal, when federal regulatory regimes leveled the playing field nationwide, and that usually was good enough. There are now many other countries involved and international approaches are necessary if state intervention and a more cooperative approach to international governance is the goal. ${ }^{45}$ If a strong state laissez-faire response is the goal, then maximum decentralization of power would further that kind of global economy. As I shall argue below, however, this should be a political decision, not one subject to constitutional dictates by the Supreme Court. It should be one subject to change by the government of the day.

In short, the transnational or horizontal character of multinational corporations involves significant independent power relationships that substantially undercut the power of states to influence these entities according to what states may perceive as their own interests. The economic power of some transnational organizations and their constraining effects on states makes them somewhat akin to states, at least in so far as their social and structural effects. ${ }^{46}$ Such private-power centers are transnational in nature and, thus, cannot easily be regulated by uniform domestic rules, even at the national level.

A global perspective on power allocation issues between federal and state governments thus provides us with additional criteria with which to evaluate the Court's federalism decisions. It also creates additional concerns when it comes to global governance and the role of individual states in that process. As we begin to analyze concepts of federalism from a global perspective, democracy and public participation questions loom large. Traditional federalism responses and calls for a return to pre-New Deal days do not necessarily solve these problems, given the global dispersion of power that now exists. Just as it is impossible to recreate the sense of the private that existed in an earlier historic era, it is impossible to view states as independent units of power, unaffected by actors and problems that do not correlate with geographic boundaries. It may be that there needs to be more local control over certain issues, but there may also need to be new forms of gov-

44. See generally Susan Strange, Casino Capitalism (1986) (comparing the Western finance and investment systems to Las Vegas casinos).

45. See Group of Lisbon, Limits to Competition xiii-xxi (1995).

46. See Diffusion of Power, supra note 43, at 54 (arguing that if one excludes war and peace and focuses more broadly on day-to-day economic issues, transnational corporations have come to play a significant role in determining "who gets what" in the world system). 
ernance and participation at the global level. Judicial approaches that unnecessarily limit these new possibilities may do more harm than good by, in effect, playing a role somewhat akin to the role the Court played as this country began, politically, to come to grips with the legal and economic implications of a national economy. ${ }^{47}$

\section{Sovereignty, Federalism, and the Court}

The Court's recent opinions declaring certain federal acts in violation of the Commerce Clause or the Tenth Amendment imply a rights conception of state sovereignty. ${ }^{48}$ Such strong-state assumptions are at odds with the fluid and multilevel mix of governmental and private partnerships characteristic of globalization within the United States. The Court's notion of state sovereignty is steeped in nineteenth century precedents, entailing a view of state power that regards member states as separate and distinct in relation to each other and relative to the federal government. Just as nation-states are not autonomous entities, individual member states are also integral to the global economy. ${ }^{49}$ Indeed while the prevailing metaphor of federalism is the vertical dimension, it is important to recognize these lateral relationships, particularly as private-public partnerships multiply and disperse power centers.

The Court's opinions also reflect an aspect of public choice theory by emphasizing accountability and cost as important bases for its decisions, especially in situations where the federal government attempts to use the apparatus of states to implement its policies. In so doing, however, the Court emphasizes the importance of differentiating clearly between the levels of government responsible for these additional costs. In its view, democracy, freedom, and liberty require that those who make decisions should be accountable to the electorate

47. See generally Ellis Hawley, The New Deal and the Problem of Monopoly (1969); see also, Archibald Cox, The Court and the Constitution 117-38 (1987).

48. See, e.g., Gregory v. Ashcroft, 501 U.S. 452 (1991); New York v. United States, 505 U.S. 144 (1992); United States v. Lopez, 514 U.S. 549 (1995); Printz v. United States, 521 U.S. 898 (1997); United States v. Morrison, 529 U.S. 598 (2000).

49. Cf. United States v. Morrison, 529 U.S. 598, 655 (2000) (Souter, J., dissenting) ("The facts that cannot be ignored today are the facts of integrated national commerce and a political relationship between States and Nation much affected by their respective treasuries and constitutional modifications adopted by the people. The federalism of some earlier time is no more adequate to account for those facts today than the theory of laissez-faire was able to govern the national economy 70 years ago."). See generally J.A. Camilleri \& J. Falk, The End of Sovereignty (1992) (discussing the effects of political theory and rhetoric on the conflict between political integration and fragmentation). 
who must pay the costs of those decisions. ${ }^{50}$ Unfunded mandates, in this sense, violate the spirit of democracy and undermine accountability for those who are responsible for their costs. ${ }^{51}$ While this may be true, it does not follow that funding for some programs might not follow along, were the politics to change so as to favor or demand it. These decisions constitutionally stop such political processes before they even begin.

\section{A. State Sovereignty}

The Court's conception of state sovereignty as self-contained in nineteenth century terms is most apparent in Gregory $v$. Ashcroft.$^{52}$ At issue in Ashcroft was Missouri's mandatory retirement law for state judges. That law had been challenged as a violation of the Age Discrimination in Employment Act (ADEA) and the Equal Protection Clause of the Fourteenth Amendment. In rejecting these claims, Justice O'Connor, writing for the majority, found that the ADEA was not applicable, using a "plain statement" statutory interpretive approach to reach that result, one infused with federalistic values and constitutional assumptions. In so doing, Justice O'Connor emphasized the sovereignty of states in a fashion that suggested a zero-sum game approach to the allocation of federal and state power. She writes:

As every schoolchild learns, our Constitution establishes a system of dual sovereignty between the States and the Federal Government. This Court has recognized this fundamental principle. In Tafflin $v$. Levitt " $[\mathrm{w}] \mathrm{e}$ beg[a]n with the axiom that, under our federal system, the states possess sovereignty concurrent with that of

50. See, e.g., United States v. Lopez, 514 U.S. 549, 577 (1995) (Kennedy, J. concurring) ("Were the Federal Government to take over the regulation of entire areas of traditional state concern, areas having nothing to do with the regulation of commercial activities, the boundaries between the spheres of federal and state authority would blur and political responsibility would become illusory."); see also Printz v. United States, 521 U.S. 898, 919 (1997) ("The Framers' experience under the Articles of Confederation had persuaded them that using the States as the instruments of federal governance was both ineffectual and provocative of federal-state conflict .... The Constitution thus contemplates that a State's government will represent and remain accountable to its own citizens.").

51. See Printz, 521 U.S. at 919.

52. 501 U.S. 452 (1991). 
the Federal Government, subject only to limitations imposed by the Supremacy Clause." 53

Justice O'Connor then goes on to quote from an 1869 case that describes the constitutional scheme of dual sovereigns in greater detail:

'[T]he people of each State compose a State, having its own government, and endowed with all the functions essential to separate and independent existence..., ' '[W]ithout the States in union, there could be no such political body as the United States.' Not only, therefore, can there be no loss of separate and independent autonomy to the States, through their union under the Constitution, but it may be not unreasonably said that the preservation of the States, and the maintenance of their governments, are as much within the design and care of the Constitution as the preservation of the Union and the maintenance of the National government. The Constitution, in all its provisions, looks to an indestructible Union, composed of indestructible States. ${ }^{.54}$

The idea of sovereignty propounded by Justice O'Connor implies a bright line between the powers of states and the national government. Her sense of that line seems strongly anchored in a sense of place typical of approaches to states prevalent in the nineteenth century. ${ }^{55}$ Such approaches minimize the zone of overlap that can (and often should) exist between two sovereigns. Once again, this concept of sovereignty is not an end in itself, but a way of securing "the citizens the liberties that derive from the diffusion of sovereign power." ${ }^{\text {I }}$ Indeed, it is like the doctrine of separation of powers: "The Constitutional authority of Congress cannot be expanded by the 'consent' of the government unit whose domain is thereby narrowed, whether that unit is the Executive Branch or the

53. Id. at 457 (quoting Tafflin v. Levitt, 493 U.S. 455, 458 (1990)(internal citations omitted)).

54. Id. (quoting Texas v. White, 7 Wall. 700, 725 (1869), (quoting Lane County v. Oregon, 7 Wall. 71, 76(1869))).

55. See Alexander B. Murphy, The Sovereign State System as Political-Territorial Ideal: Historical and Contemporary Considerations, in State Sovereignty As Social Construct 81-93, 100-02 (Thomas J. Biersteker \& Cynthia Weber eds., 1996).

56. New York v. United States, 505 U.S. 160, 181 (1992). 
States." 57 The Court believes that sovereignty, so conceived, is essential to the infrastructure of policymaking. Not unlike the doctrine of separation of powers aimed at preventing the aggregation of power by any one branch of government, federalism and state sovereignty also reflect commitment to distributed power as a basis for civil liberty. As Justice O'Connor notes:

This federalist structure of joint sovereigns preserves to the people numerous advantages. It assures a decentralized government that will be more sensitive to the diverse needs of a heterogen[e]ous society; it increases opportunity for citizen involvement in democratic processes; it allows for more innovation and experimentation in government; and it makes government more responsive by putting the States in competition for a mobile citizenry. ${ }^{58}$

Indeed, in the majority's view, the constitutional scheme requires clear lines demarcating the powers exercised by the states from those exercised by the national government. "Just as the separation and independence of the coordinate branches of the Federal Government serve to prevent the accumulation of excessive power in any one branch, a healthy balance of power between the States and the Federal Government will reduce the risk of tyranny and abuse from either front." ${ }^{59}$

The notion of sovereignty on which the Court's rationales are based fails to consider that many private actors within states have power on the level of states themselves. ${ }^{60}$ Justice Breyer, speaking for the four Justices who often dissent together in recent federalism cases, emphasized the potential negative ramifications of the Court's decisions on the effectiveness of government in his dissent in Federal Maritime Commission v. South Carolina Ports Authority. ${ }^{61}$ In that case, the Court held that state sovereign immunity prevented Congress from compelling a state to answer the complaints of private parties before the administrative

57. Id. at 182.

58. Gregory v. Ashcroft, 501 U.S. 452, 458 (1991).

59. Id.

60. See Ian Harden, The Contracting State 7-8 (1992); see also Patrick Birkinshaw et al, Government by Moonlight: The Hybrid Parts of the State (1990).

61. 535 U.S. 743, 786 (2002) (Breyer, J. dissenting). 
tribunal of a federal agency. ${ }^{62}$ Breyer argued that federal administrative agencies are not covered by the Eleventh Amendment since they do not exercise the judicial power of the United States. ${ }^{63} \mathrm{He}$ adds that the practical consequences of the opinion are negative:

The decision, while permitting an agency to bring enforcement actions against States, forbids it to use agency adjudication in order to help decide whether to do so. Consequently the agency must rely more heavily upon its own informal staff investigations in order to decide whether a citizen's complaint has merit. The natural result is less agency flexibility, a larger federal bureaucracy, less fair procedure, and potentially less effective law enforcement .... At least one of these consequences, the forced growth of the unnecessary federal bureaucracy, undermines the very constitutional objectives the Court's decision claims to serve. $^{64}$

When viewed from a global context, the goals mentioned by the Court's federalist majority (heterogeneity, democracy, innovation, and a mobile citizenry) look different from when they are seen as a function of federal and state power operating jointly, but alone. Global competition and the incentives for states to attract and retain private foreign investment encourage integration rather than difference. Moreover, most states seek to minimize public costs so as to maximize their appeal to private investment. Thus, while democracy may very well be furthered by keeping certain issues local, globalization creates important pressures toward transnationalism at the local level, where minority interests may have even fewer procedural protections than at the federal level. Thus, federalist privileging of the local may be at the expense of a more vibrant national democracy, one that allows citizens an opportunity not only to vote and express themselves, but, crucially, to form coalitions across state boundaries giving minority groups a greater chance to aggregate their power and to speak in a more audible voice. Indeed, the kind of segmented citizenship that the Court espouses does not accord with the complex realities and multiple citizenship identities

62. Id. at 760 .

63. Id. at 777 (Breyer, J. dissenting).

64. See id. at 785-86. 
that the global economy produces. ${ }^{65}$ Federalism denationalizes issues and it unbundles the concept of citizenship, fragmenting our political responses and further disaggregating the public.

More important, public innovation, too, is likely to be homogenized and only take the form of minimal taxes and lower regulatory costs, though this, in turn, may encourage more private experimentation. Yet, the greater the number of activities that move from the public realm to the private sector, the greater the risk that global currency coined at the local level will be at the expense of the weakest members of society. ${ }^{66}$ The intense competitiveness that this model encourages may, indeed, encourage more mobility among citizens in their quest to find a modicum of financial stability. Such mobility, though, will most likely occur at the higher end of the income spectrum, rather than the lower. ${ }^{67}$ Freedom in the sense of making national action more difficult to achieve may be enhanced, but at the expense of developing a more cooperative model of global capitalism at the international and national levels. Greater decentralization may also lead to a race to the bottom in some areas, ${ }^{68}$ but more importantly, it raises the transaction costs involved in achieving more cooperative approaches to coping with the problems of global capitalism and the externalities of globalization. ${ }^{69}$

The idea of a state's integrity is at the basis of the majority's opinion in New York v. United States. ${ }^{70}$ Once again, the Court is more concerned with the forms of power, rather than with structures that make it easy to exercise power in a flexible way. In this case, the Court dealt with the constitutionality of the LowLevel Radioactive Waste Policy Amendments Act of 1985. The Act in question was the result of various state efforts to devise a federal structure for the regulation of low-level waste that avoided federal preemption and retained a role for states to play. In many ways, the legislative process was akin to the negotiation

65. See, e.g., Dennis Conway, Are There New Complexities In Global Migration Systems of Consequence For the United States "Nation-State"?, 2 Ind. J. Global Legal Stud. 31, $35-43$ (1994) (discussing international mobility, the world as an interconnected community, and how individuals relate to and identify with more than one country at a time).

66. See William Greider, One World, Ready or Not 360-87 (1997). See generally Gary Teeple, Globalization and the Decline of Social Reform 69-74 (1995) (discussing the move from nationalism to globalization as it affects financial theory).

67. See generally Saskia Sassen, Cities in a World Economy (1994).

68. See Esty, supra note 23, at 627-38.

69. See Rubin and Feeley, supra note 25.

70. 505 U.S. 144 (1992). 
and the enactment of a treaty, whereby the individual states involved retained considerable flexibility when it came to meeting their regulatory obligations. The Act was the result of a cooperative approach to federalism that allows states to maintain flexibility and the primary regulatory role in their traditional realm of protecting public health and safety. ${ }^{71}$ The federal government set the basic standards, but rather than pre-empting state law, the Act allowed states to design policies their lawmakers believed best achieved the federal standards. ${ }^{72}$ As one commentator noted: "In theory, the system allows states to experiment and innovate, but not to sacrifice public health and welfare in a bidding war to attract industry."73

Specifically, Congress sought to achieve its federal goals by creating certain incentives to ensure that states provide for the disposal of radioactive waste generated within their borders. States were authorized to impose a surcharge on radioactive waste received from other states, a portion of which would be collected by the Secretary of Energy and placed in a trust account for those states that achieved a series of milestones in developing waste disposal sites. ${ }^{74}$ States were also authorized to increase the costs of access to sites to those states that did not meet federal guidelines, eventually denying them access altogether.

None of these "incentives" violated the Court's sense of state sovereignty. A third incentive, however, provided that a state that fails to provide for the disposal of all internally generated waste by a particular date must, in most cases, take title to and possession of the waste and become liable for all damages suffered by the waste's generator or owner as a result of the state's failure to

71. As Justice White described it, concurring in part and dissenting in part:

[The Act] resulted from the efforts of state leaders to achieve a state-based set of remedies to the waste problem. They sought not federal pre-emption or intervention, but rather congressional sanction of interstate compromises they had reached. [The] 1985 Act was very much the product of cooperative federalism, in which the States bargained among themselves to achieve compromises for Congress to sanction .... Unlike legislation that directs action from the Federal Government to the States, the [Congressional action] reflected hard-fought agreements among States as refereed by Congress. Id. at 189-90, 194.

72. See generally Adam Babich, Our Federalism, Our Hazardous Waste, and Our Good Fortune, 54 MD. L. Rev. 1516 (1995) (discussing the application of this notion to the example of hazardous waste control).

73. Id. at 1532-33.

74. 505 U.S. at 152. 
promptly take possession. ${ }^{75}$ For the Court, this provision created constitutional problems. ${ }^{76}$ In rejecting Congress' attempt to force certain states to take title to and possession of low-level waste, the Court emphasized that Congress could not force the states to regulate in ways that made them direct agents of the federal government. Congress could regulate individuals, but not states, because states were sovereign:

In providing for a stronger central government, therefore, the Framers explicitly chose a Constitution that confers upon Congress the power to regulate individuals, not States. As we have seen, the Court has consistently respected this choice. We have always understood that even where Congress has the authority under the Constitution to pass laws requiring or prohibiting certain acts, it lacks the power directly to compel the States to require or prohibit those acts. The allocation of power contained in the Commerce Clause, for example, authorizes Congress to regulate interstate commerce directly; it does not authorize Congress to regulate state governments' regulation of interstate commerce. ${ }^{77}$

In the majority's view, "[t]he take title provision offers state governments a 'choice' of either accepting ownership of waste or regulating according to the instructions of Congress. " ${ }^{\prime 8}$ Either type of federal action would "commandeer" state governments into the service of federal regulatory purposes, and would for

75. Id. at $153-54$.

76. Writing for the majority, Justice O'Connor noted:

The actual scope of the Federal Government's authority with respect to the States has changed over the years, therefore, but the constitutional structure underlying and limiting that authority has not. In the end, just as a cup may be half empty or half full, it makes no difference whether one views the question at issue in these cases as one of ascertaining the limits of the power delegated to the Federal Government under the affirmative provisions of the Constitution or one of discerning the core of sovereignty retained by the States under the Tenth Amendment. Either way, we must determine whether any of the three challenged provisions of the LowLevel Radioactive Waste Policy Amendments Act of 1985 oversteps the boundary between federal and state authority. Id. at 159.

77. See id. at 166.

78. Id. at 175. It is interesting to note that New York was involved in the political process that produced this result. The Supreme Court, however, rejected arguments to the effect that New 
this reason be inconsistent with the Constitution's division of authority between federal and state governments.

In short, the Court's concept of state sovereignty precludes states from entering into agreements to take certain kinds of actions to carry out their promises in the federal legislative process-unlike countries that enter into a treaty and agree to enact certain enabling legislation to realize its goals.

The Court's more recent federalism decisions take the principles of democracy, accountability and cost a step further. In Printz $v$. United States,${ }^{79}$ for example, the Court struck down the Brady Handgun Violence Prevention Act on grounds that the federal government was, in effect, commandeering the state's enforcement apparatus to carry out a federal policy. There was little doubt that Congress had the power to regulate in this area, but it could not force states to carry out its mandates. Writing for the majority, Justice Scalia emphasized the structural rather than the textual nature of this decision. ${ }^{80} \mathrm{He}$ also emphasized democracy and accountability:

We held in New York that Congress cannot compel the States to enact or enforce a federal regulatory program. Today we hold that Congress cannot circumvent that prohibition by conscripting the State's officers directly. The Federal Government may neither issue directives requiring the States to address particular problems, nor command the States' officers, or those of their political subdivisions, to administer or enforce a federal regulatory program. It matters not whether policymaking is involved, and no case-by-case weighing of the burdens or benefits is necessary; such commands are fundamentally incompatible with our constitutional system of dual sovereignty. ${ }^{81}$

York had, in effect, consented to these federal regulations, stating that "[w]here Congress exceeds its authority relative to the States the departure cannot be ratified by the 'consent' of state officials." Id. at 182. Compare id. at 198-205 (discussing how the states just wanted Congress to sanction their agreement) (White, J., dissenting).

79. 521 U.S. 898 (1997).

80. Id. at $932-33$.

81. Id. at 935 . 
As Justice Stevens emphasized in dissent, the result in this case had no textual basis in the Constitution. ${ }^{82}$ More important for our purposes, it relied once again on a concept of sovereignty with little bearing on global realities. Only Justice Breyer chose to see this case in comparative-if not global terms-noting that no other federal system in the world today would prevent the use of state enforcement powers in this way. ${ }^{83}$

Viewed from a global perspective, the "all or nothing" quality of the Court's approach both overstates and understates what is at stake. It overstates the potential restructuring effects of power flowing from one body to another, as power has flowed from the states to the federal government for over two hundred years. In a global economy, multi-governmental approaches may often be necessary and power arrangements should be more fluid. Constitutionalizing these decisions removes a good deal of this flexibility. At the same time, the Court's approach to power levels also understates what is at stake to the extent that it overlooks entirely the fact that nonstate actors, especially transnational corporations, are now major power centers, in many ways comparable to states. Thus, a concept of federalism that does not include a sense of how global power is allocated today runs the serious risk of undermining the very goals it seeks to further - democracy and liberty. It may be that moving some decisions to the national level can more easily neutralize inappropriate uses of private power. Be that as it may, constitutionalizing certain results removes an important political option.

\section{B. The Commerce Power}

Apart from issues involving the use of a state's own enforcement apparatus, the ability of Congress to regulate at the national level has also been limited by the Court's view of the commerce power. In United States $v$. Lopez ${ }^{84}$ the constitutionality of the Gun-Free School Zone Act of 1990 was at issue. This Act "made it a federal offense 'for any individual knowingly to possess a firearm at a

82. Id. at 944 (Stevens, J., dissenting).

83. See id. at 976 (Breyer, J., dissenting) ("At least some other countries, facing the same basic problem, have found that local control is better maintained through application of a principle that is the direct opposite of the principle the majority derives from the silence of our Constitution. The federal systems of Switzerland, Germany and the European Union, for example, all provide that constituent states, not federal bureaucracies, will themselves implement many of the laws, rules, regulations, or decrees enacted by the central 'federal' body.").

84. 514 U.S. 549 (1995). 
place that the individual knows, or has reasonable cause to believe, is a school zone." ${ }^{85}$ For the majority, this was "a criminal statute that by its terms has nothing to do with 'commerce' or any sort of economic enterprise, however broadly one might define those terms." ${ }^{86}$ Moreover, according to the majority, the argument that guns in a school zone may result in violent crime that substantially affects interstate commerce proves too much. "Thus, if we were to accept the Government's arguments, we are hard pressed to posit any activity by an individual that Congress is without power to regulate." 87 Indeed, the majority feared that a decision holding this Act to be within Congress' Commerce Clause power would convert Congressional authority under that clause to a general police power of the sort retained by States. The Court thus concluded that the commerce power was not infinitely expandable, and that there are limitations "inherent in the very language of the Commerce Clause." 88

Justices Kennedy and O'Connor concurred, emphasizing the policy benefits of a governmental structure that divides power between federal and state authorities: "the theory that two governments accord more liberty than one requires for its realization two distinct and discernable lines of political accountability: one between the citizens and the Federal Government; the second between the citizens and the States." 89

This kind of separation was crucial for true accountability to occur:

If, as Madison expected, the federal and state governments are to ... hold each other in check by competing for the affections of the people, those citizens must have some means of knowing which of the two governments to hold accountable for failure to perform a given function.... Were the Federal Government to take over the regulation of entire areas of traditional state concern, areas having nothing to do with the regulation of commercial activities, the boundaries between the spheres of federal and state authority would blur and political responsibility would become illusory. ${ }^{90}$

85. Id. at 551 (quoting 18 U.S.C. $\S 922(\mathrm{~g})(1)$ (A) (Supp. V 1988)).

86. Id. at 561 .

87. Id. at 564 .

88. Id. at 553 .

89. Id. at 576 .

90. Id. at 576-77. 
These policy justifications for the textual interpretation given by the majority are very much based on a conception of the state as a unitary entity, where citizens clearly differentiate among those who exercise power. Of course, citizens of the states also have a vote at the federal level and the idea that they are easily fooled by the federal level of government at the expense of the states may not give sufficient credit to the discerning nature of the voters involved. But quite apart from the policy arguments, there is the broader claim that guns, violence and the global economy are all interrelated, especially when education is involved.

In his dissenting opinion in Lopez, Justice Breyer takes a very different perspective on this case, focusing more on the school children involved and on the interrelationships between education and the national economy and beyond." Indeed, he emphasizes that education and business are directly related: "technological changes and innovations in management techniques have altered the nature of the workplace so that more jobs now demand greater educational skills." ${ }^{92}$ Three Justices joined in dissent, but Justice Breyer was the only Justice to make the link between the national economy and global competition:

[G]lobal competition also has made primary and secondary education economically more important. The portion of the American economy attributable to international trade nearly tripled between 1950 and 1980, and more than 70 percent of Americanmade goods now compete with imports. Yet lagging worker productivity has contributed to negative trade balances and to real hourly compensation that has fallen below wages in 10 other industrialized nations. At least some significant part of this serious productivity problem is attributable to students who emerge from classrooms without the reading or mathematical skills necessary to compete with their European or Asian counterparts. ${ }^{93}$

Justice Breyer seems to have a clear concept of global competition. His premise is that every school child will eventually compete for jobs against other

91. Id. at 620 .

92. Id.

93. Id. at 621 (internal citations omitted). 
school children all over the globe. Local jobs and prosperity will turn on the outcome of this competition. He notes "there is evidence that, today more than ever, many firms base their location decisions upon the presence, or absence, of a work force with a basic education." ${ }^{.94}$ For Justice Breyer, guns, education, and business are interrelated: "The economic links I have just sketched seem fairly obvious." 95 He questions "Why then is it not equally obvious, in light of those links, that a widespread, serious, and substantial physical threat to teaching and learning also substantially threatens the commerce to which that teaching and learning is inextricably tied?" 96

For Justice Breyer, the links between local violence, education, and success in the global economy are sufficiently direct to justify federal involvement. Though he takes a global perspective on the issues before him, his judicial approach to the commerce clause is reminiscent of Wickard $v$. Filburn. ${ }^{97}$ Though Justice Breyer is quick to add that his approach does not "obliterate the distinction between what is national and what is local," $" 98$ his willingness to define the national interest by looking beyond national borders to an interdependent global economy, represents an approach that ultimately would vest most regulatory decisions at the federal level, should the national government decide to act. ${ }^{99}$ In short, globalization does not necessarily render concepts of state sovereignty based on territory irrelevant, but a national government intent on maximizing

94. Id.

95. Id. at 622.

96. Id. at $622-23$.

97. 317 U.S. 111, 127-29 (1942). (upholding the application of the Agricultural Adjustment Act to the planting and consumption of homegrown wheat)

98. United States v. Lopez, 514 U.S. 549, 557 (1995).

99. One could argue that Justice Breyer's approach proves too much, i.e., the links between global and domestic economies are so apparent as to assure a federal result. As this article argues, the distinction between the global and various forms of the local has collapsed; this does not mean Congress must automatically act. It is not compelled to act. Rather, the issues are now political issues to be acted on in the political process, without such judicial intervention, as contemplated in Lopez. Justice Stevens argues state sovereignty is protected through the political process: "[i]t is the Framers' compromise giving each State equal representation in the Senate that provides the principal structural protection for the sovereignty of the several States." Kimel v. Florida Bd. of Regents, 528 U.S. 62, 93 (2000) (Stevens, J., dissenting in part and concurring in part). He adds that, "[f]ederalism concerns do make it appropriate for Congress to speak clearly when it regulates state action. But when it does so... we can safely presume that the burdens the statute imposes on the sovereignty of the several States were taken into account during the deliberative process leading to the enactment of the measure. Id. at 96. 
competitiveness in a global economy is at cross purposes with itself when it opts to constitutionalize such issues rather than seek a national, political consensus.

Perhaps the Court should not be faulted for analyzing federalism issues in a framework that is dominated by nineteenth century concepts of federalism embodied in nineteenth century precedents. Yet, in the Court's effort to re-establish what often appears to be a pre-New Deal position vis-à-vis national power, it is overlooking an aspect of New Deal judicial processes that remains highly relevant for the global state. As just noted, courts should avoid constitutionalizing issues when it is not necessary to do so. Though the Court may have been concerned with costs unnecessarily imposed on states, such matters are best dealt with legislatively. Diluted federal power need not be the inevitable outcome of the global state, and courts need not be drawn into taking the lead in sculpting the state of the future. It is ironic that at the edge of the twenty-first century, the Court would opt for constitutional approaches that unduly limit legislative flexibility. The New Deal Court constitutionalized a political approach to issues. The Rehnquist Court is constitutionalizing outcomes that unbundle the use of federal power and, in the process, citizenship as well.

In suggesting that the Court's approach to federalism is insufficiently attuned to the current fluidity and multi-centeredness of federal/state/private power, I do not wish to be misread as advocating that the Court lend its authoritative weight to globalization. Rather, I am suggesting that its construction of federalism as entailing (or requiring) a preference for discrete powers of member states is unlikely to achieve the goal of widening the political process. Quite the contrary, local jurisdictions may be far more exposed to market constraints than the country at large, with the result that citizens' roles in democratic deliberation are likely to be less substantial as a counter-weight to globalization, for example, than at the federal level. In other words, a strict approach to federalism is likely to increase the democracy deficit. In globalization, federalism is a form of denationalization no less than the international public sphere and the transnationalized private sector more often associated with this concept.

\section{ConClusion}

These denationalizing effects of federalism privilege markets and market outcomes, underscoring the extent to which our current national policy looks to the market as an arena of delegation and to market incentives as a substitute for traditional regulation. The politics that produces these results in Congress has 
been emphatically reinforced in the Court's opinions in terms of the rhetoric of its federalism decisions and in a way far more rigid than a purely political decision to place responsibility at the state instead of the federal level of government. As we have just seen, this is particularly apparent in Supreme Court decisions over the last decade or so.

The relationship between federalism and the democracy deficit may seem counter-intuitive. Indeed, throughout the federalism cases discussed above, a persistent rationale provided by the Court for its decisions is that the Court seeks to increase democracy by ensuring that power in matters involving state issues be exercised by officials closer to the people directly affected. The idea that democracy is enhanced if power is exercised geographically closer to those affected tends to overstate territory and distance as general criteria for democracy. More to the point, it ignores the "divide and conquer" effect that the denationalization of decision making can have, particularly with regard to issues involving new challenges on behalf of marginal constituents. Delegating power down or, in effect, devolving power to the states, fragments minority and marginal constituencies, sometimes to the point that these groups are effectively excluded. Sending Head Start programs or other programs for the poor back to the state, without specific federal funding and guidelines, makes such funding vulnerable to the needs and politics of those states that may neither have the resources necessary nor the political will for such programs. Though the theory of devolution is that it increases democracy by bringing decisions closer to stakeholders, it can have the opposite effect when those stakeholders are widely dispersed.

The likelihood of control by powerful local groups increases with decentralization of political authority. As Professors Crenson and Ginsburg have pointed out:

Madisonian logic suggests that small constituencies are more likely than large ones to fall under the domination of a single interest. Its hegemony may discourage opposing groups from mobilizing, or it may use its political privilege to structure local institutions so that other interests find it difficult to organize. Organization ... is the mobilization of bias; some interests can be organized into politics while others are organized out. ${ }^{100}$ 
Quite apart from the intrusive role that courts now play in these contexts, there are strong political and economic incentives at the state level that argue pervasively for the devolution of regulatory and safety net issues. Given the increasing competition that exists now at all levels of government for the attraction and retention of economic investment to their respective territories, devolving welfare responsibility or housing for the poor to the state level, for example, means individual states will vary in their approaches to such issues and in the priority they give to them. The financial capabilities of the states vary. Moreover, as states compete for investment and the retention of taxpayers, they have distinct incentives to minimize the costs of redistributive programs such as welfare, Medicaid, or poverty programs in general. Some states will reduce payments for these programs more than others because of lack of funds; others, for ideological reasons. Differences in state wealth and a politics of choice in such contexts, tend to make poor constituencies far more vulnerable than when these interests are aggregated at the national level. ${ }^{101}$ Political decisions such as these however, can always be reversed. But when courts constitutionalize such issues, they lock in these outcomes for generations to come, in effect taking them out of national politics, and in reality, local politics as well.

When choices of interpretive approaches to constitutional doctrines exist, those approaches that preserve, increase, or further the flexibility of decisionmakers' responses to the global economy should be preferred. Not unlike the New Deal era when the Court had to confront new issues arising from society's political responses to a newly emerging nationally integrated economy, the Court today decides issues against a backdrop of an increasingly integrated economy. An analysis of recent federalism decisions shows that it is important that courts resist constitutional approaches that unnecessarily limit change or new power-sharing approaches to both new and old issues. The deferential, constitutional interpretive approaches forged by the Court during the New Deal era may, in fact, be best suited for the political experimentation now necessary, especially if various levels of government and non-state actors are to adapt successfully to the realities of a global economy. This position, however, is not an argument for a return to the New Deal as far as substance is concerned. There is no going back to the twentieth century or to the state-centric future that courts and law makers have envisioned for the greater part of this nation's history. 


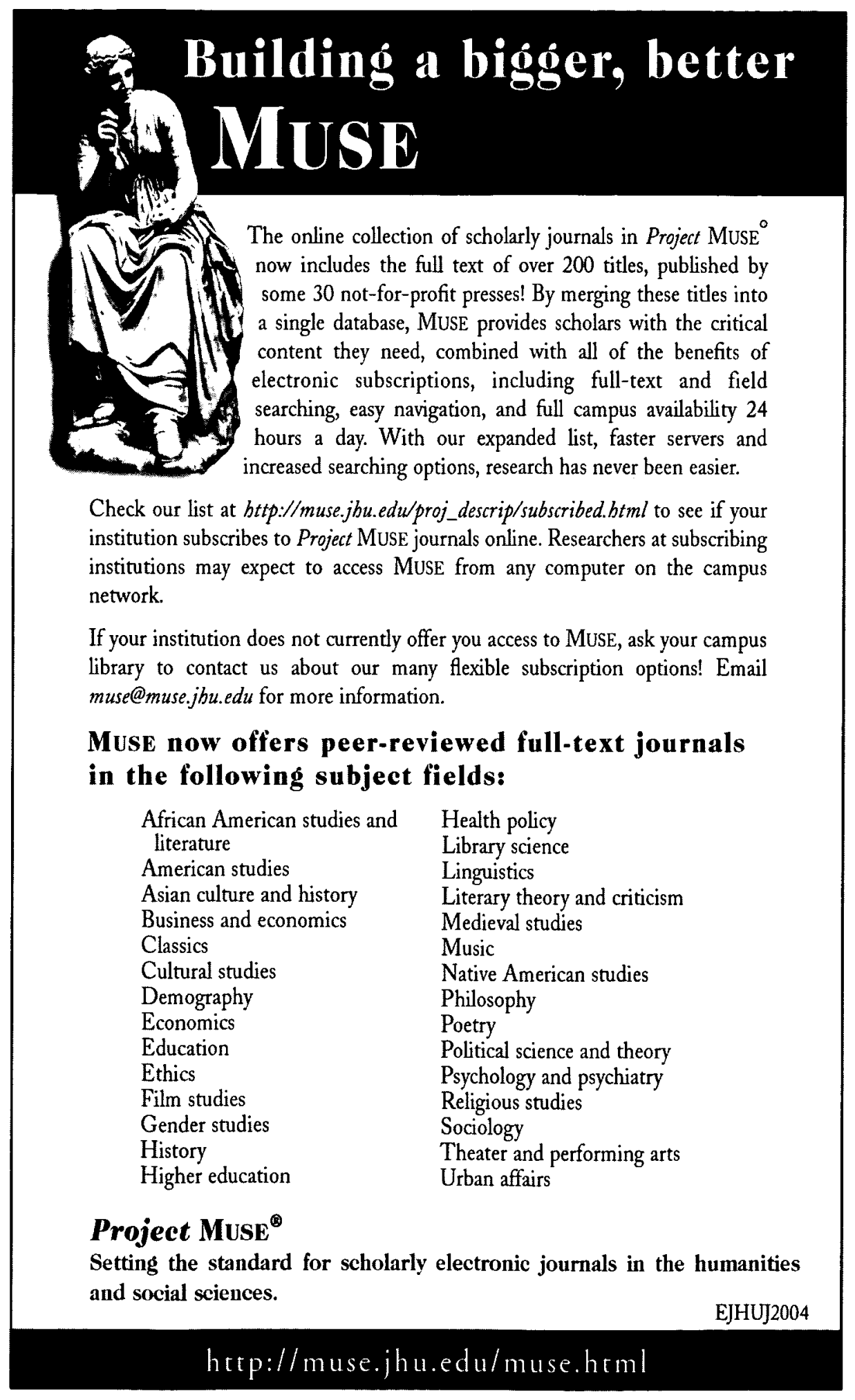

